\title{
Self-Drive Tourism Route in Terengganu: An Application of Goal Programming Model
}

\author{
Zakiah Hashimª*, Wan Rosmanira Ismail ${ }^{b}$ \\ aSchool of Quantitative Sciences, College of Art and Sciences, Universiti Utara Malaysia, 06010 UUM, Sintok, Kedah Darul Aman, Malaysia. \\ ${ }^{b}$ School of Mathematical Sciences, Faculty of Science and Technology, Universiti Kebangsaan Malaysia,43600 UKM Bangi, Selangor, Malaysia. \\ *Corresponding author: zakiah@uum.edu.my
}

\begin{abstract}
This study presents a goal programming approach to determine the best self-drive tourism route in Terengganu. The goal programming was formulated based on the model of Traveling Salesman Problem (TSP). This study involved seven cities in Terengganu which can be connected by road network. The data of the tourist attractions for each city was used in this study. The model of self-drive tourism route was constructed so as to connect all these seven cities by minimizing the travel distance, minimizing accommodation costs and maximizing the total number of tourist attractions. To achieve the objectives of this study, we develop the goal programming model that considers three model structures with each of them consists three goal constraints which are subjected to four hard constraints. This model has been solved using LINGO12.0 software. The results obtained from each model structures will be compared in order to get the most optimum route for self-drive tourism. The result showed that the first model structure was suitable to be used because this model structure gave the optimum result compared to other model structures. It produced the minimum total traveling cost of RM967.70 compared to the model structure two of RM977.10 and model structure three of RM1233.10.
\end{abstract}

Keywords: Goal programming model; self-drive tourism; tourism route; traveling salesman problem; Terengganu

\section{Abstrak}

Kajian ini menggunakan pendekatan pengaturcaraan gol untuk menentukan laluan pelancongan pandu sendiri yang optimum di Terengganu. Pengaturcaraan gol ini diformulasi berasaskan kepada model masalah jurujual kembara (TSP). Kajian ini melibatkan tujuh bandar di Terengganu yang boleh dihubungkan oleh rangkaian jalan raya. Data berkaitan tempat pelancongan menarik bagi setiap bandar telah digunakan dalam kajian ini. Model laluan pelancongan pandu sendiri telah dibina bagi menghubungkan kesemua tujuh bandar yang terlibat dengan matlamat untuk meminimumkan jarak perjalanan, meminimumkan kos penginapan dan memaksimumkan jumlah tempat pelancongan yang boleh dilawati. Untuk mencapai objektif kajian ini, kami telah membangunkan model pengaturcaraan gol yang mempertimbangkan tiga struktur model; setiap daripada model ini mempunyai tiga kekangan matlamat yang tertakluk kepada empat kekangan tegar. Model ini seterusnya diselesaikan dengan menggunakan perisian LINGO12.0. Keputusan yang diperolehi daripada setiap struktur model akan dibandingkan untuk mendapatkan laluan yang paling optimum bagi pelancongan pandu sendiri. Hasil kajian mendapati bahawa struktur model yang pertama adalah sesuai digunakan kerana struktur model ini memberikan hasil yang optimum berbanding dengan dua struktur model yang lain. Ia menghasilkan jumlah kos perjalanan yang paling minimum iaitu sebanyak RM967.70 berbanding model struktur dua iaitu sebanyak RM977.10 dan model struktur tiga iaitu RM1233.10.

Kata kunci: Model pengaturcaraan gol; pelancongan pandu sendiri; laluan pelancongan; masalah jurujual kembara; Terengganu

(C) 2017 Penerbit UTM Press. All rights reserved

\subsection{INTRODUCTION}

Tourism denotes the temporary, short-term movement of people to destinations outside the places where they normally live and work, and their activities during the stay at these destinations (Burkart \& Medlik, 1981). Theobald (1994) suggested that etymologically, the word "tour" is derived from the Latin 'tornare' and the Greek 'tornos', meaning "a lathe or circle; the movement around a central point or axis." This meaning changed in modern English to represent "one's turn." The suffix -ism is defined as "an action or process; typical behavior or quality," whereas the suffix -ist denotes one that performs a given action. When the word "tour" and the suffixes -ism and ist are combined, they suggest the action of movement around a circle. One can argue that a circle represents a starting point, which ultimately returns back to its beginning. Therefore, like a circle, this represents a journey that is a round trip, i.e., the act of leaving and then returning to the original starting point. Thus, one who takes such a journey can be called a tourist. According to World Tourism Organization (UNWTO) (2011), "Tourism comprises the activities of persons traveling to and staying in place outside their usual environment for not more than one consecutive year for leisure, business and other purposes." Tourism is the study of human from its original habitat in which to respond to the industry and will also have an impact on the social, economic and physical environment (Mason 2003 in Jaffry \& Nor Azlina, 2007). The main purpose of travel is to visit tourist attractions around the location.

In both developed and developing countries, tourism is one of the fastest-growing sectors of the economy and major source of employment and investment (Wearing et al., 2010). According to the World Tourism Organization of the United Nations (UNWTO) (2011), Malaysia is the $9^{\text {th }}$ most visited in the world from 2009 to 2011 . Malaysia is the only country in Southeast Asia and second in Asia 
after China, which received the largest number of tourist arrivals during 2011. In 2011, Malaysia recorded total foreign tourist arrivals of 24.7 million people with total revenues worth RM58.3 billion. This achievement is in line with Malaysia Tourism Transformation Plan 2020 which aims arrival of 36 million tourists with a revenue of RM168 billion in 2020 (Tourism Malaysia Corporate Website, 2012). Various tourism products have been offered in the country including the resorts have island and hill, a shopping destination and the main event, conferences market, incentives, conventions and exhibitions, sports tourism and recreation, ecotourism, tourism based on agriculture, program stay with the family, theme parks, cultural and heritage tourism and tourism education, students and health (Nasruddin \& Bushra, 2012). To promote a culture of self-drive tourism in Malaysia, Ministry of Tourism Malaysia has organized the 'Malaysia Tourism Hunt 2012' program on 20 to 25 September 2012 with the concept of' 'Fly \& Drive '. It can encourage the self-drive tourists to enjoy the interesting sight along the road of Malaysia (Harian Metro, 13 September, 2012). Self-drive tourism represents a type of tourism where tourists driving their own or rented car as the primary mode of transport.

Study by Hardy (2006) states that self-drive tourism is an important market sector in the Canada and North America. His research also states that self-drive tourists are traveling on their own vehicles or use their own recreational vehicles including five wheel vehicles, motor homes and caravans. Based on the above statements, self-drive tourism is define as the tourism that is carried out by driving their own vehicle or hires a vehicle to the places of interest. Olsen (2002) has been defined that self-drive tourism as travelling from home at least one night for the purpose of holiday or visiting friends or relatives by driving their own or rented vehicle as the primary mode of transport. By using this mode of travel, tourists can plan their own itinerary without being tied to a travel itinerary from a travel agency. According to Hsin (2006), one of the important features of self-drive tourism is tourists can plan their own itinerary? Self-drive tourism is linked to the concept of special interest tourism, where the tourists have specific purposes (usually activity based) for visiting destinations (Carson et al., 2002). Self-drive tourism is usually a free travel. Tourists can determine or choose their own preferred route from a destination to the next destination in accordance with the provisions on travel costs and time required. Best route selection is important for self-drive tourists because it will affect the amount of travel costs, time to travel and also the number of places can be visited. If the self-drive tourists make the mistakes in choosing a route to the destination, they will face the problem of rising costs and lack of time travel. According to Taplin $\&$ McGinley (2000), for most holiday makers traveling by car, the pursuit of satisfaction and enjoyment is limited by the length of time available and by travel distance.

There are a variety of tourist destinations to visit in Malaysia and one of them is Terengganu. Terengganu was selected as a case study because it is often the focus of tourists whether from within or outside the country. Terengganu often get a place in the hearts of tourists because of its still rich in natural beauty, adventure activities and the excitement of reliving colourful tradition and heritage kept alive. The state of Terengganu which has one of the longest coastlines in Malaysia has been widely regarded as the cradle of Malay culture in Malaysia. The state of capital Kuala Terengganu has an abundance of appeals with attractions offering glimpses of unique blend of local tradition, rich cultures, heritage and the beauty of nature, plus the warmth of its people. Due to the elongated shape of the country map, it makes a journey taken to reach a destination from a previous destination rather long and time-consuming.

The tourism industry is one of the major sources that contribute to national income. Meanwhile, in the state of Terengganu, the state government will further strengthen the tourism industry as a source of income for the state after petroleum. In conjunction with Visit Terengganu Year 2013, Terengganu had reached the target attendance of 4 million tourists and generate revenue of RM2 billion. While in the year 2014, Terengganu has received approximately 4.5 million domestic and overseas tourists (teganukita.my, 2015). An increasing number of tourists are not only capable encouraging domestic economy and attract investors even improve the living standard of population, especially those involved in the business. Self-driving is an alternative way to facilitate visitors to Terengganu. If tourists want to have a convenience trip and do not want to be bound by the traveling schedule, they can drive the car without the tourist guide or driver and they can develop their own itineraries. According to Carson et al. (2002), self-drive tourism has advantages to tourists in terms of: greater control over itinerary; often greater comfort and lower cost.

For the tourism industry, transport is the key factor in enabling tourists to travel from their place of residence to the place where they wish to go. For the purpose of this paper, the key of the transport here is to enabling tourists to travel from origin to interesting places by self-drive. In many tourism studies, the relationship between transport and tourism is defined in terms of accessibility; that is transport is seen as a link between tourist generating regions and tourism destination regions. For travel to and within destinations, the choice of which mode of transport are used may depend on the travelers' evaluation of speed; carrying capacity; comfort; cost; and safety. Because this study involved only land and road links, the selection mode of vehicles used by tourists only ground vehicles such as cars, vans and others.

The aim of this paper is to determine the best route of a self-drive tour in Terengganu using a goal programming model. The tourists can visit interesting places around Terengganu with minimum travel distance and the accommodation cost and also maximize the number of tourist attractions.

\subsection{LITERATURE REVIEW}

Tourism is seen as an industry that contributes to the economic growth of government and the private sector, especially after the Second World War (1939-1945). To encourage the development of tourism, the government provides appropriate policies and strategies to make tourism as a new source of economic growth. The development of tourism in a destination contributed a variety of positive impacts on the economic, environmental and social, such as socio-economic status of the population, the increase in environmental quality and promote the relationship between tourists and residents. Therefore, various studies using various mathematical programming models are carried out from time to time in order to enhance effectiveness and improvement in the tourism industry.

Goal programming is a relatively new tool that has been proposed as a model and approach for the analysis of problems involving multiple, conflicting objectives. The earliest goal programming formulation was introduced by Charnes et al. (1955) in the context of executive compensation and Ignizo (1976) brought the technique into common usage as an operational research tool. Seely et al. (1980) has used goal programming approach to the planning process of tourism organizations by changing priorities of goals, budgetary limitations, and organizational constraints. They found that by utilizing goal programming, a tourism organization can more systematically evaluate the nature and relative importance of organizational goals, critical constraints affecting the organization and marketing program alternatives. Zografos \& Oglethorpe (2004) has applied multi-criteria analysis using goal programming to assess the appropriate solution to 
the problem of eco-tourism. The case studies in Ecuador, review issues related to strategic planning and management of ecological tourism by using the method of weighted goal programming.

Zakiah \& Wan Rosmanira (2012), has applied a goal programming model for self-drive tourism route selection in Langkawi that based on the model of Traveling Salesman Problem (TSP), with three goal constraints which are minimizing total travel times, minimizing travel cost and minimizing accommodation cost. Nasruddin \& Bushra (2012), has used a goal programming technique to assess the management tourism's activities and the economic impact on Wetland Putrajaya. Blancas et al. (2010), proposes a methodology for obtaining a synthetic indicator to facilitate decision making in practical situations that based on goals provided by the users, which will be included in a synthetic indicator by a goal-programming approach. They used this methodology to study the case of coastal areas of Andalusia (Spain), attempting to identify the main characteristics of the different elements, their weakness and strengths. To determine the tourist carrying capacity, Carillo \& Jorge (2006), have applied the multi objective techniques in their study. They proposed the use of methods within the field of vector programming for a multi objective analysis of a tourist destination. Besides tourism, goal programming model is also developed in the other areas such as transportation (Miori, 2011), healthcare (Azaiez, 2005), education (Pan, 2009), manufacturing (Selen, 1986), business (Yahia-Berrouiguet, 2015) and so on.

\subsection{PROBLEM DEFINITION}

This paper presents a study on a real road network that connects a city to another city in Terengganu. A total of seven cities involved in this study, namely Bandar Permaisuri, Jerteh, Kuala Terengganu, Marang, Kuala Berang, Dungun and also Chukai (refer Figure 1). These cities was selected for this study because they can be contacted directly by the road network without being repetitive. In addition, there are many interesting tourist attractions around these cities.

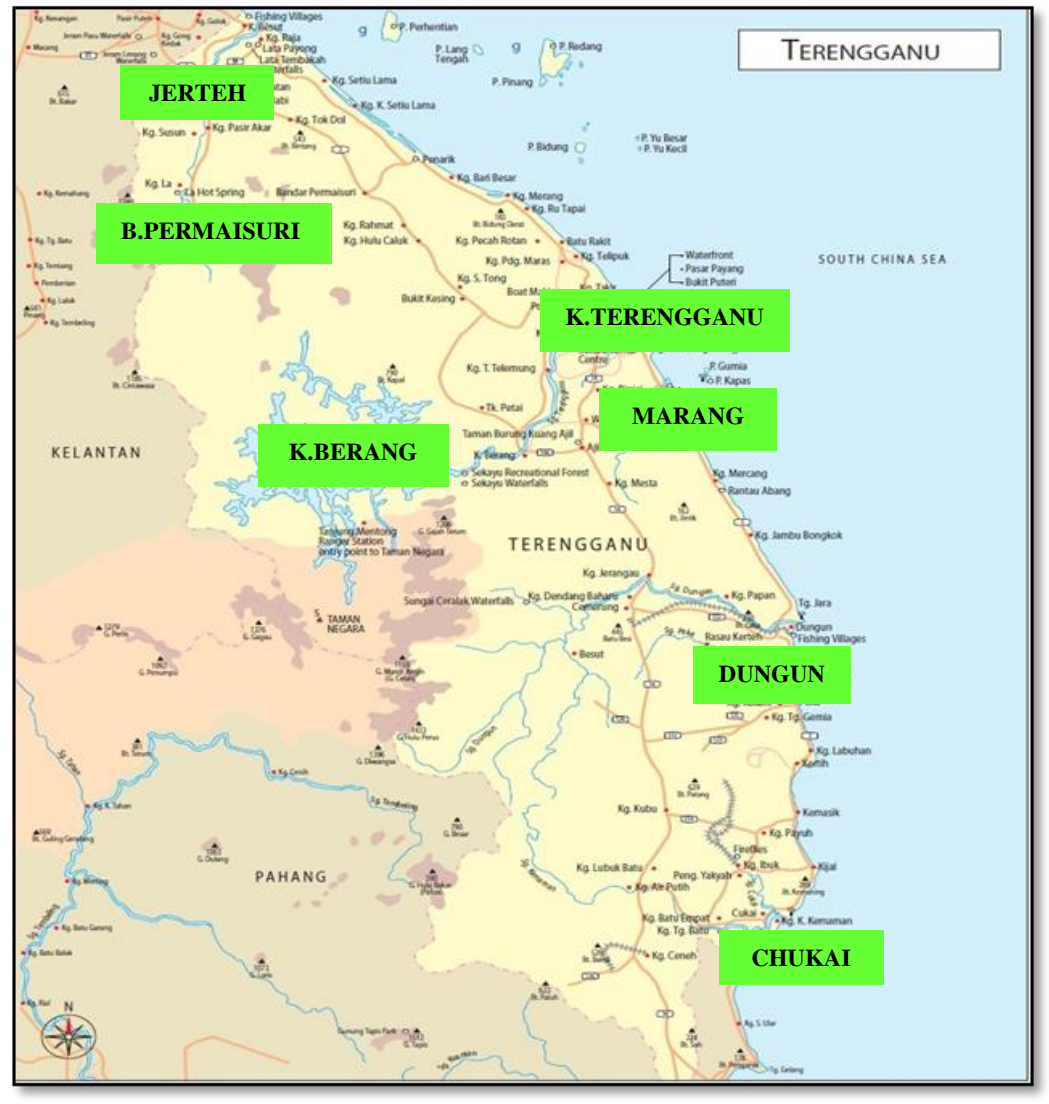

Figure 1 Maps of Terengganu

Apart from driving a road data, this study also includes data for interesting destinations available in seven cities and along the way from one city to another city. All data was obtained from the Ministry of Tourism Terengganu, Terengganu State Secretary and searching in Google Maps. In addition, due to the scope of our study focused on self-drive tour, it involved only the tourist attractions that can be reached by ground vehicle. Table 1 shows the number of tourist attractions for each city and also the estimated visiting times (hour) for all tourist attractions. 
Table 1 Number of tourist attractions for each city and estimated visiting times (hour)

\begin{tabular}{cccc}
\hline City & Abbreviation & Number of tourist attractions & Estimated visiting times (hour) \\
\hline Kuala Terengganu & KT & 23 & 69 \\
Kuala Berang & KB & 8 & 24 \\
Bandar Permaisuri & BP & 5 & 15 \\
Jerteh & J & 11 & 33 \\
Marang & M & 5 & 15 \\
Dungun & D & 14 & 42 \\
Chukai & C & 11 & 33 \\
\hline
\end{tabular}

The focus of this study is to develop the goal programming model that based on traveling salesman problem (TSP) for self-drive tourism in Terengganu. The travelling salesman problem (TSP) is perhaps the most well known combinatorial optimization problem. The TSP is to find a shortest route of a traveling salesman that starts at a home city, visits a prescribed set of other cities and returns to the starting city in such a way that the total distance traveled is minimized and each city is visited exactly once (Gutin, 2004). Kuala Terengganu was chosen as the depot developing the TSP model. This means that for all visitors who arrives in Terengganu, the first and final destination of their travel is Kuala Terengganu. In order to develop the model, we need make an assumption regarding on the total time provided for travel a day. The total time allocated for travel was at least 12 hours per day which is included the time to travel from one place to another place and also the time to visit each tourist attraction. Estimated travel time to visit interesting places that exists between one city to another city is obtained from the estimated time given by the Google Maps application for each selected path. The distance from one city to another city were also found using the Google Maps application. In addition, due to many tourist attractions for each city, the assumptions for 3 hours allocated time to visit each tourist attractions was made. This assumption was made depending on the places and also of the demands of tourists themselves. If the tourists prefer to relax on the beach, tourists may spend more than 3 hours on the beaches and allocate less than 3 hours for shopping. Therefore, the best assumption is approximately 3 hours allocated time to visit a particular place and to facilitate the calculation is done, the right choice for 3 hours to estimate the time to visit tourists attractions that are along the way and around the city. RON95 petrol type was chosen in this study because its price is less expensive at RM1.95 per liter compared to RON97 which is RM2.45 per liter. The average of estimated distance of one liter petrol is 10 kilometers. This means that the fuel cost per kilometer is RM0.195. Estimated cost of rental vehicle per day (24 hours) is RM80.00.

\subsection{MODEL FORMULATION}

Based on Ignizio (1976), linear goal programming model commonly like:

Find $x=\left(x_{1}, x_{2}, \ldots, x_{n}\right)$ so that

Minimize the lexicography $\left(P_{1}\left(d^{-}, d^{+}\right), \ldots, P_{k}\left(d^{-}, d^{+}\right)\right)$

Subject to: $\quad f_{i}(x)+d^{-}-d^{+}=b_{i}$,

$x, d^{-}, d^{+} \geq 0 \quad$ for $i=1,2, \ldots, m$

with $f_{i}(x)$ is a mathematical representation of the objective $i$ as a function of decision variables $x=\left(x_{1}, x_{2}, \ldots, x_{n}\right), b_{i}$ is the level of aspiration associated with the objectives $i$ and $d^{-}, d^{+}$respectively is a negative and the positive deviation variables of each goal. If $P_{l}$ represents a priority level associated with the main goal set and $P_{2}$ associated with the next set of goals and so forth, it was found that a compliance to the goals related to $P_{k}$ is more than compliance to the goal of a major less $P_{k+1}, P_{k+2, \ldots}$, then with a given priority when compared to compliance with a major less set (Hillier \& Lieberman, 2010).

\subsection{Decision variables}

The decision variables used in this problem is a binary variable that is 0 or 1 . Here is the decision variables used:

$$
x_{i j}=\left\{\begin{array}{l}
1 ; \text { if there is a path from city } i \text { to } j \\
0 ; \text { otherwise }
\end{array}\right.
$$

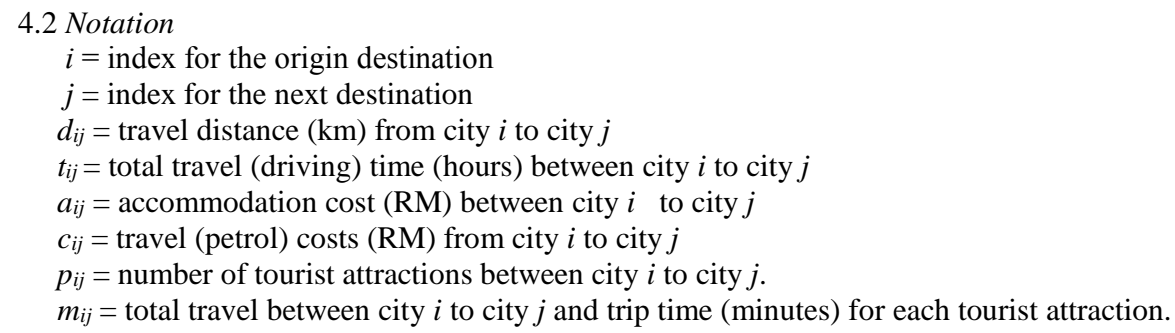


$P_{\min }=$ minimum total number of visited tourist attractions in 14 days (75 places)

$M_{\max }=$ maximum total travel between city $i$ to city $j$ and trip time (minutes) for each tourist attraction (10680 minutes @ 178 hours)

The model used here is goal programming (GP) model that based on traveling salesman problem (TSP). This model has 3 objectives which are subject to four goal constraints and four hard constraints. The four objectives are:

1. Minimize total travel distance to visit all seven cities and tourist attractions in Terengganu.

2. Minimize the total accommodation cost in Terengganu.

3. Maximize the total number of visited tourist attractions in Terengganu.

The goal constraints are:

Goal 1: Minimize the positive deviation to minimize the total travel distance.

Goal 2: Minimize the positive deviation to minimize total accommodation cost.

Goal 3: Minimize the negative deviation to maximize total number of visited tourist attractions.

$$
\begin{aligned}
& \sum_{i=1}^{7} \sum_{j=1}^{7} d_{i j} x_{i j}+d_{1}^{-}-d_{1}^{+}=D_{\max } \\
& \sum_{i=1}^{7} \sum_{j=1}^{7} a_{i j} x_{i j}+d_{2}^{-}-d_{2}^{+}=A_{\max } \\
& \sum_{i=1}^{7} \sum_{j=1}^{7} p_{i j} x_{i j}+d_{3}^{-}-d_{3}^{+}=P_{\min }
\end{aligned}
$$

Meanwhile the hard constraints involved are:

1. Tourists arriving in each city only once.

2. Tourists leaving out of each only once.

3. The number of days for the whole trip does not exceed the maximum number of days set for the whole journey.

4. Constraints to prevent the sub-tour. Sub-tour is a round tour that returns back to the starting city but does not visit all the cities.

$$
\begin{aligned}
& \sum_{i=1}^{7} \sum_{j=1}^{7} m_{i j} x_{i j} \leq M_{\max } \\
& \sum_{i=1}^{7} x_{i j}=1 ; j=1,2, \ldots ., 7 ; i \neq j \\
& \sum_{j=1}^{7} x_{i j}=1 ; i=1,2, \ldots, 7 ; j \neq i \\
& u_{i}-u_{j}+7 x_{i j} \leq 6 ; i \neq j ; i=1,2, \ldots, 7 ; j=1,2, \ldots, 7
\end{aligned}
$$

Now, we can formulate a linear programming (LP) that minimizes the cost incurred in deviating from the three goals, i.e. minimizing the function of the deviation variables. In this study, since we are not able to determine precisely the relative importance of each goal, preemptive goal programming is used instead. We must denote the most important goal as $P_{1}$, the secondary goal as $P_{2}$ and the least important goal as $P_{3}$. We then develop an objective function where we put $P_{1}$ being the first priority level $1, P_{2}$ priority level 2 and $P_{3}$ priority level 3 . Since we cannot also determine the rank of each goal, we will use the different order of importance of each goal.

Hence, there are four model structures involved in this study. This means that for the model structure 1, the travel distance constraint goals have to be at the priority 1 and for model structure 2, the accommodation constraints goal was set as the first priority and for model structure 3, total number of visited tourist attractions was set as the first priority.

Here is the goal programming model for model structure 1:

Minimize $P_{1} d_{1}^{+}, P_{2} d_{2}^{+}, P_{3} d_{3}^{-}$

Subject to:

$$
\begin{aligned}
& \sum_{i=1}^{7} \sum_{j=1}^{7} d_{i j} x_{i j}+d_{1}^{-}-d_{1}^{+}=600 \\
& \sum_{i=1}^{7} \sum_{j=1}^{7} a_{i j} x_{i j}+d_{2}^{-}-d_{2}^{+}=500 \\
& \sum_{i=1}^{7} \sum_{j=1}^{7} p_{i j} x_{i j}+d_{3}^{-}-d_{3}^{+}=75 \\
& \sum_{i=1}^{7} \sum_{j=1}^{7} m_{i j} x_{i j} \leq 10680 \\
& \sum_{i=1}^{7} x_{i j}=1 ; j=1,2, \ldots ., 7 ; i \neq j
\end{aligned}
$$




$$
\begin{aligned}
& \sum_{j=1}^{7} x_{i j}=1 ; i=1,2, \ldots ., 7 ; j \neq i \\
& u_{i}-u_{j}+7 x_{i j} \leq 6 ; i \neq j ; i=1,2, \ldots, 7 ; j=1,2, \ldots, 7 \\
& x_{i j} \in\{0,1\}, \forall_{i, j}=1,2, \ldots, 7 ; d_{1}^{-}, d_{1}^{+}, d_{2}^{-}, d_{2}^{+}, d_{3}^{-}, d_{3}^{+} \geq 0
\end{aligned}
$$

Constraint (1) shows that travel distance for 14 days does not exceed 600 kilometers. Constraint (2) shows that accommodation cost for 14 days does not exceed RM500 and constraint (3) shows that total number of visited tourist attractions for 14 days does not less than 75 places. Meanwhile constraint (4) shows that total travel and trip time for visiting all tourist attractions does not exceed 10680 minutes (178 hours). Constraint (5) shows that tourists can arrive in each city only once and constraint (6) shows that tourists can leave each city only once. Meanwhile constraint (7) is to avoid sub-tours. Constraints for model structures 2 and 3 remain same with the model structure 1 , except the objective function changed.

Objective function for model structure 2 is:

Minimize $P_{1} d_{2}^{+}, P_{2} d_{3}^{-}, P_{3} d_{1}^{+}$

Objective function for model structure 3 is:

Minimize $P_{1} d_{3}^{-}, P_{2} d_{1}^{+}, P_{3} d_{2}^{+}$

\subsection{RESULTS AND DISCUSSION}

To obtain results for the goal programming model, LINGO software version 12.0 was used. LINGO is a comprehensive computer software and effective way to solve the problem of modeling linear and non-linear with the faster, easier and effectively (Schrage, 2006). In addition, LINGO is also a mathematical modeling language that allows us to express the optimization problem in a similar form to standard mathematical notation.

Based on Table 2, Kuala Terengganu (KT) is the starting and ending point for the trip of all the four model structures. The total number of days to visit all the seven cities and selected tourist attractions in this study was 14 days. Since the time allocated per day for this trip is 12 hours, so tourist will stay for that night at the final destination that has reached 12 hours journey by staying at a nearby hotel (accommodation) with the lowest price. The accommodation was selected based on location that are closed to tourist areas in a radius less than $5 \mathrm{~km}$ and spent less than 8 minutes to the tourist attractions. Accommodation varies for each day trip depending on time constraints provided 12 hours a day to travel. So, tourists stayed at the different hotel for the whole 14 days trip.

Table 2 Travel route of model structure 1, 2 and 3

\begin{tabular}{cc}
\hline Structure & Route \\
\hline 1 & $\mathrm{KT} \rightarrow \mathrm{J} \rightarrow \mathrm{BP} \rightarrow \mathrm{KB} \rightarrow \mathrm{D} \rightarrow \mathrm{C} \rightarrow \mathrm{M} \rightarrow \mathrm{KT}$ \\
2 & $\mathrm{KT} \rightarrow \mathrm{BP} \rightarrow \mathrm{J} \rightarrow \mathrm{KB} \rightarrow \mathrm{D} \rightarrow \mathrm{C} \rightarrow \mathrm{M} \rightarrow \mathrm{KT}$ \\
3 & $\mathrm{KT} \rightarrow \mathrm{BP} \rightarrow \mathrm{J} \rightarrow \mathrm{C} \rightarrow \mathrm{D} \rightarrow \mathrm{M} \rightarrow \mathrm{KB} \rightarrow \mathrm{KT}$ \\
\hline
\end{tabular}

Based on the results obtained from the three model structures in Table 3, it shows only model structure 1 and 2 reached all the priority level. Since the accommodation cost for model structure 3 exceeds the maximum allocation of accommodation cost, thus this proves that this priority level is not reached. The solution given by the three model structures shows that only one of the most appropriate model to use, which is model structure 1 . Model structure 1 produced the minimum travel distance, minimum travel (petrol) cost and also minimum accommodation cost with maximum total number of visited tourist attractions. It produced the minimum total traveling cost of RM967.70 compared to the other two model structure.

Table 3 Summary of solutions for model structure 1, 2 and 3

\begin{tabular}{cccccc}
\hline Structure & Travel distance $(\mathbf{k m})$ & Travel (petrol) cost $(\mathbf{R M})$ & Accommodation cost $(\mathbf{R M})$ & Tourist attractions & Total cost $(\mathbf{R M})$ \\
\hline 1 & 521.90 & 101.77 & 344.00 & 77 & 967.67 \\
2 & 523.10 & 102.00 & 352.00 & 75 & 977.10 \\
3 & 537.20 & 116.90 & 579.00 & 76 & 1233.10 \\
\hline
\end{tabular}

\subsection{CONCLUSION}

Based on this study, the used of proposed model is proven to give an idea to the tourists in choosing a suitable route when they want to visit tourist attractions in Terengganu by drive their own vehicle. It shows that the proposed model was expected to help tourists make their travel plan guidance in order to choose the route that will minimize the travel distance, travel (petrol) cost and accommodation cost with maximum total number of visited tourist attractions.

Any weaknesses of this study need to be improved so that a better outcome can be obtained. One of the suggestions for improvement this model is to consider more carefully other relevant information such as the time and entrance cost to particular sightseeing tour and 
time set by a tour of the place. With this, the budget allocation and spending time set capable of satisfying the requirements of self-drive tourists.

\section{References}

Azaiez, M. N., \& Al Sharif, S. S. (2005). A 0-1 Goal Programming Model for Nurse Scheduling. Computers \& Operations Research, $32,491-507$.

Blancas, F. J., Caballero, R., González, M., Lazano-Oyola, \& M., Pérez, F. (2010). Goal Programming Synthetic Indicators: An Application for Sustainable Tourism in Andalusia Coastal Counties. Ecological Economics, 69(11), 2158-2172.

Burkart, A. J., \& Medlik, S. (1981). Tourism: Past,Present and Future, $2^{\text {nd }}$ ed. London: William Heinemann Ltd.

Carillo, M., \& Jorge, J. (2006). Multiobjective Decision Support for the Tourist Sector. Revista Investigación Operacional, 27(2), 84-92.

Carson, D., Waller, I., \& Scott, N. (2002). Drive Tourism: Up the Wall and Around the Bend. Melbourne: Common Ground Publishing Pty Ltd.

Charnes, A., Cooper, W. W., \& Ferguson, R. (1955). Optimal Estimation of Executive Compensation by Linear Programming. Management Science, 1, 138-151.

Gutin, G., \& Punnen, A. P. (2004). The Traveling Salesman Problem and Its Variations. New York: Kluwer Academic Publishers.

Hardy. A. (2006). Understanding Self Drive Tourism (Rubber Tire Traffic): A Case Study of Bella Coala, British Columbia. University of Northern British Columbia. $\mathrm{Ph} . \mathrm{D}$ Thesis.

Harian Metro. 13 September 2012. Retrieved from http://www.hmetro.com.my/articles/130sediaberentap/Article. (2 January 2013).

Hillier, F. S., \& Lieberman, G. J. (2010). Introduction to Operations Research, 9th ed. New York: McGraw-Hill.

Hsin, Y. S. (2006). Network Characteristics of Drive Tourism Destinations: An Application of Network Analysis in Tourism, Tourism Management, 27, 1029-1039.

Ignizio, J. P. (1976). Goal Programming and Extensions. Lexington, MA: Lexington Books.

Jaffry Zakaria \& Nor Azlina Abdullah. (2007). Pelancongan Rekreasi Berasaskan Cabaran dan Biodiversiti: Isu dan Konflik. Retrieved from http://www.academia.edu (10 August 2015).

Miori, V. M. (2011). A Multiple Objective Goal Programming Approach to the Truckload Routing Problem. Journal of the Operational Research Society, 62(8), 1524-1532.

Nasruddin Hassan \& Bushra Abdul Halim. (2012). Pemodelan Matematik dalam Pengurusan Aktiviti Pelancongan Rekreasi di Wetland Putrajaya. Sains Malaysiana, 41(9), 1155-1161.

Olsen, M. (2002). Keeping Track of the Self Drive Market. In D. Carson, I. Waller, \& N. Scott. Drive Tourism: Up the Wall and Around the Bend. Melbourne: Common Ground Publishing Pty Ltd.

Pan, L., Chu, S.C. K., Han, G., \& Huang, J. Z. (2009). Multi-criteria Student Project Allocation: A Case Study of Goal Programming Formulation with DSS Implementation. The Eighth International Symposium on Operations Research and Its Applications (ISORA'09), Zhangjiajie, China.

Schrage, L.(2006). Optimization Modelling with Lingo,6th ed. USA: Lindo System Inc.

Seely, R. L., Iglarsh, H.J., \& Edgell, D. L. (1980). Goal Programming: Planning Process of Tourism Organizations. Annals of Tourism Researh, 7(3), 353-365.

Selen,W. J., \& Hott, D. D. (1986). A Mixed-Integer Goal-Programming Formulation of the Standard Flow-Shop Scheduling Problem. The Journal of the Operational Research Society, 37(12), 1121-1128.

Taplin, J. H. E., \& McGinley, C. (2000). A Linear Program to Model Daily Car Touring Choices. Annals of Tourism Research, 27(2), 451-467.

Theobald, W. F. (1994). Global Tourism: The Next Decade. Oxford, London: Butterworth-Heinemann.

United Nation World Tourism Organization (UNWTO). (2011). Collection of Tourism Expenditure Statistics, UNWTO Technical Manual No. 2.

Wearing, S., Stevenson, D., Young, T. (2010). Tourist Cultures: Identity, Places and the Traveller. London: SAGE Publications Ltd.

Yahia-Berrouiguet, A., \& Tissourassi, K. (2015). Application of Goal Programming Model for Allocating Time and Cost in Project Management: A Case Study from the Company of Construction Seror. Yugoslav Journal of Operations Research, 25(2), 283-289.

Zakiah Hashim \& Wan Rosmanira Ismail. (2012). Goal Programming Model for Self-drive Tourism Route Selection: A Case Study in Langkawi. In Zainal et al. (eds). Current Issues in Hospitality Research and Innovations. London: Taylor \& Francis Group.

Zografos, C., \& Oglethorphe, D. (2004). Multi-criteria Analysis in Ecotourism: Using Goal Programming to Explore Sustainable Solutions. Current Issues in Tourism $7(1), 20-43$ 